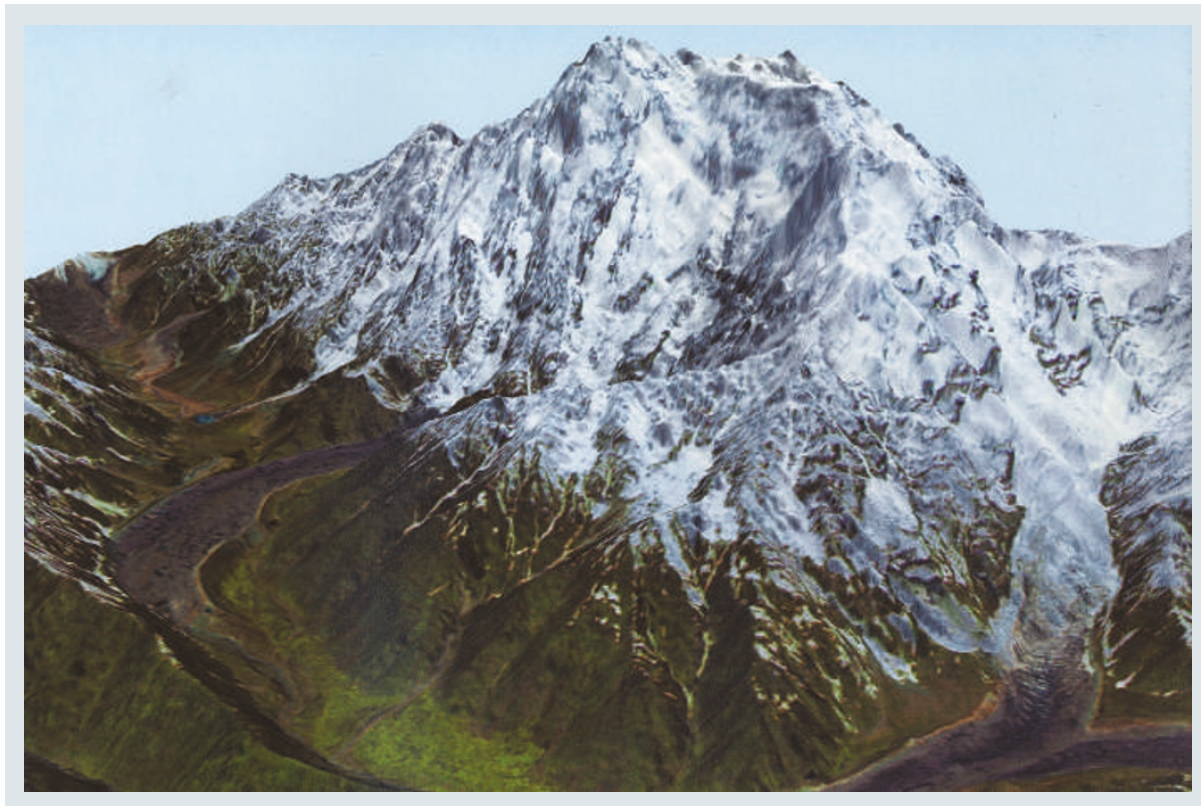

\title{
On top of the world
}

\author{
Nanga Parbat in Pakistan, the ninth highest \\ mountain in the world, is one of 90 or so \\ mountains included in Mountains From Space: \\ Peaks and Ranges of the Seven Continents. This \\ striking book, which contains photos taken from \\ space, is published by the German Aerospace \\ Centre (DLR) and Harry N. Abrams, and is \\ available in German and English editions. \\ Taking its name from the Sanskrit for 'sacred \\ mountain', Nanga Parbat is 8,125 metres high \\ and has cost many mountaineers their lives, \\ including Günther Messner, whose brother and \\ climbing partner Reinhold came up with the \\ idea of the book. Reinhold Messner is among \\ several authors who provide essays from their \\ perspectives as mountaineers or scientists. \\ This picture was taken by the SPOT- 5 Earth- \\ observation satellite.

\section{EXHIBITION}

\section{A close look at Darwin}

\section{Darwin \\ American Museum of Natural History, \\ New York, until 29 May 2006. \\ www.amnh.org/exhibitions/darwin}

\section{Alan Packer}

The American Museum of Natural History in New York bills its new exhibition, Darwin, as the most in-depth ever mounted on Charles Darwin's life and thought. It's also well timed, coming as it does in the midst of litigation over 'intelligent design' in Dover, Pennsylvania, and in the run-up to the bicentennial of Darwin's birth in 2009. All that aside, Darwin is splendid: evolutionary biologist Niles Eldredge's exhibition takes us on a fascinating tour through the life of a great thinker, in what is a superb example of the curator's art.

Visitors are greeted at the entrance by a live, and somehow mesmerizing, giant tortoise from the Galapagos (it can also be viewed remotely via webcam at the exhibition's website). They then encounter Darwin's magnifying glass. This serves as an iconic image throughout the exhibition, a magnifying glass is positioned to allow the viewer a closer look at a specimen, symbolizing the overall theme of Darwin's lifelong devotion to close observation of nature. His theoretical conclusions, which are well explained in the exhibition, rest on a mountain of evidence that he saw with his own eyes. That evidence is presented here in abundance.

There are many noteworthy items on display, including original correspondence, specimens from Darwin's own collection, original notebooks, and pressed plants from the voyage of the Beagle. The writing box that belonged

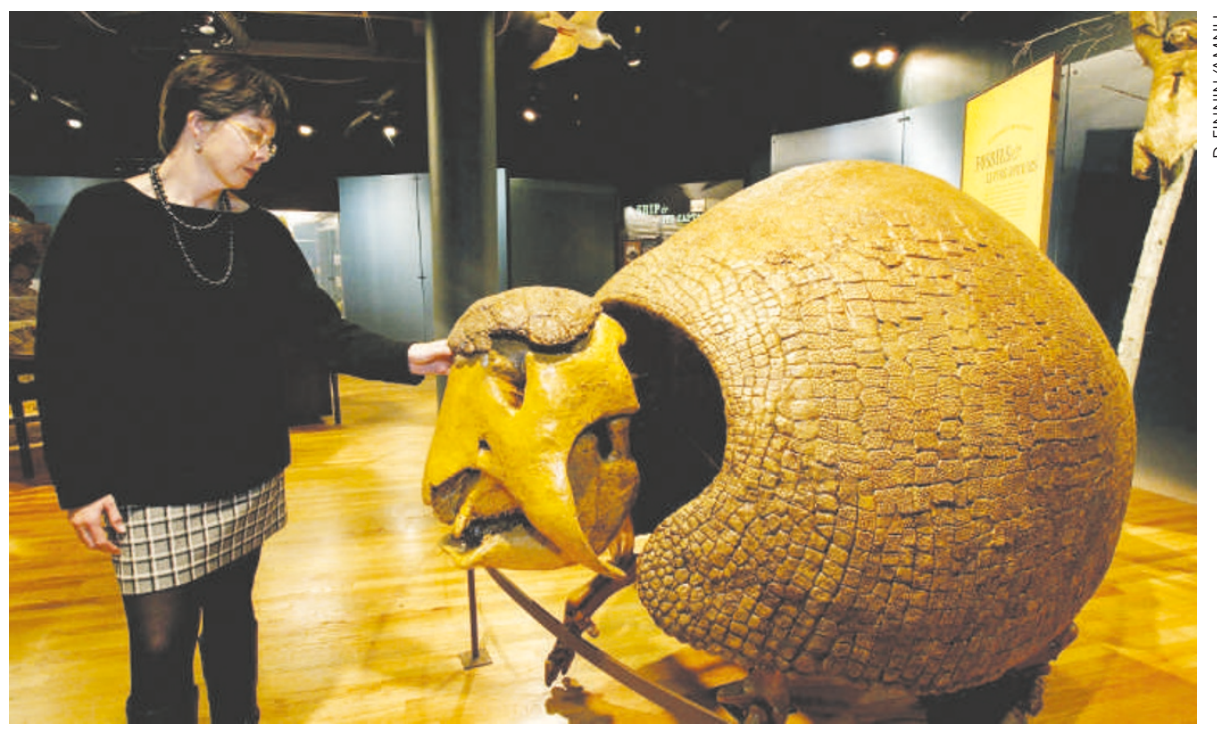

Among other exhibits, visitors to Darwin can see a cast of a glyptodont skeleton found by Darwin.

to his daughter Annie is included here (she died at the age of 10). So too is an amusingly exhaustive questionnaire that Darwin sent to 'gentleman farmers', enquiring about their experiences with artificial breeding. The atmosphere is congenial: sounds of ocean life are heard in the section devoted to Darwin's voyage on the Beagle; there is a 'condensedtime' video of the 'Sandwalk' footpath around Darwin's home and workplace, Down House in Kent, UK; and in the exit room, a voiceover of the final words from Darwin's book On The Origin of Species ushers you through a collection of orchids.

"Believing is easy, and knowing is hard, and it's knowing that matters most," wrote Neil
Patterson in his introduction to cell biologist Christian de Duve's recent book Singularities (Cambridge University Press, 2005). Darwin removed the nebulous idea of belief from the discussion. In explaining what we know about the theory of evolution and its originator, given the limitations of what an exhibition can convey, Darwin could hardly be bettered.

When the Darwin exhibition closes at the American Museum of Natural History in New York on 29 May 2006, it will travel to the Museum of Science in Boston, The Field Museum in Chicago, the Royal Ontario Museum in Toronto and the Natural History Museum in London.

Alan Packer is senior editor at Nature Genetics. 